\title{
Age-related changes in the upper respiratory microbiome are associated with SARS-CoV-2
}

Jillian H. Hurst, $\mathrm{PhD}^{1,2}$, Alexander W. McCumber, $\mathrm{MS}^{3}$, Jhoanna N. Aquino, BS ${ }^{1}$, Javier Rodriguez, $\mathrm{AS}^{4}$,

Sarah M. Heston, MD ${ }^{1}$, Debra J. Lugo, MD ${ }^{1}$, Alexandre T. Rotta, MD ${ }^{5}$, Nicholas A. Turner, MD, MHSc ${ }^{6}$,

Trevor S. Pfeiffer, BS ${ }^{1}$, Thaddeus C. Gurley, $\mathrm{MS}^{7}$, M. Anthony Moody, MD ${ }^{1,7}$, Thomas N. Denny, MSc,

MPhil $^{7}$, John F. Rawls, $\mathrm{PhD}^{8,9}$, Christopher W. Woods, MD, MPH ${ }^{6,7}$, Matthew S. Kelly, MD, MPH ${ }^{1,9}$

${ }^{1}$ Department of Pediatrics, Division of Infectious Diseases, Duke University School of Medicine,

Durham, North Carolina, USA; ${ }^{2}$ Children's Health and Discovery Institute, Department of Pediatrics,

Duke University School of Medicine, Durham, North Carolina, USA; ${ }^{3}$ Civil and Environmental

Engineering Department, Duke University, Durham, North Carolina, USA; ${ }^{4}$ Children's Clinical Research

Unit, Department of Pediatrics, Duke University School of Medicine, Durham, North Carolina, USA;

${ }^{5}$ Department of Pediatrics, Division of Pediatric Critical Care Medicine, Duke University School of Medicine, Durham, North Carolina, USA; ${ }^{6}$ Department of Medicine, Division of Infectious Diseases, Duke University School of Medicine, Durham, North Carolina, USA; ${ }^{7}$ Duke Human Vaccine Institute, Duke University School of Medicine, Durham, North Carolina, USA; ${ }^{8}$ Department of Molecular Genetics and Microbiology, Duke University School of Medicine, Durham, North Carolina, USA; ${ }^{9}$ Duke Microbiome Center, Duke University School of Medicine, Durham, North Carolina, USA

Summary: Evaluation of nasopharyngeal microbiome profiles in children, adolescents, and young adults with a SARS-CoV-2-infected close contact identified specific bacterial species that vary in abundance with age and are associated with SARS-CoV-2 susceptibility and the presence of SARS-CoV-2associated respiratory symptoms. 
medRxiv preprint doi: https://doi.org/10.1101/2021.03.20.21252680; this version posted March 23, 2021. The copyright holder for this preprint (which was not certified by peer review) is the author/funder, who has granted medRxiv a license to display the preprint in perpetuity.

All rights reserved. No reuse allowed without permission.

1 Keywords: COVID-19; community; pediatric; children; nasopharyngeal microbiome; Corynebacterium;

2 Dolosigranulum

3

4 Corresponding Author:

5 Matthew S. Kelly, MD, MPH

$6 \quad 2301$ Erwin Road

7 Durham, NC 27710

8 Phone: (919) 684-6335

9 Email: matthew.kelly@duke.edu 
medRxiv preprint doi: https://doi.org/10.1101/2021.03.20.21252680; this version posted March 23, 2021. The copyright holder for this preprint (which was not certified by peer review) is the author/funder, who has granted medRxiv a license to display the preprint in perpetuity.

All rights reserved. No reuse allowed without permission.

\section{ABSTRACT}

3 Children are less susceptible to SARS-CoV-2 and typically have milder illness courses than adults. We 4 studied the nasopharyngeal microbiomes of 274 children, adolescents, and young adults with SARS-CoV-

52 exposure using 16S rRNA gene sequencing. We find that higher abundances of Corynebacterium

6 species are associated with SARS-CoV-2 infection and SARS-CoV-2-associated respiratory symptoms,

7 while higher abundances of Dolosigranulum pigrum are present in SARS-CoV-2-infected individuals

8 without respiratory symptoms. We also demonstrate that the abundances of these bacteria are strongly,

9 and independently, associated with age, suggesting that the nasopharyngeal microbiome may be a

10 potentially modifiable mechanism by which age influences SARS-CoV-2 susceptibility and severity. 
1 SARS-CoV-2, the etiological agent of coronavirus disease 2019 (COVID-19), has resulted in more than

2100 million infections and two million deaths globally [1]. In contrast to most other respiratory viruses [2-

3 4], children appear to be less susceptible to SARS-CoV-2 infection, and SARS-CoV-2-infected children

4 typically have milder illness courses than adults. In a recent meta-analysis that included 32 studies of

541,640 children and adolescents less than 20 years of age and 268,945 adults 20 years of age or older,

6 children and adolescents were estimated to have a $46 \%$ lower susceptibility to SARS-CoV-2 infection

7 than adults [5]. Further, a higher incidence of SARS-CoV-2 infection has been observed with increasing

8 age, even among infants, children, and adolescents [6]. Reporting data from a community-based study of

SARS-CoV-2 infections, we previously demonstrated that at least one-third of SARS-CoV-2-infected children and adolescents are asymptomatic [7], and children who do develop symptomatic SARS-CoV-2 infection typically report mild respiratory symptoms [7-10]. Additionally, COVID-19 hospitalization rates and mortality among children are substantially lower than among adults of all ages, with only 576 hospitalizations and 208 deaths among children and adolescents less than 18 years of age reported during the first six months of the pandemic in the United States [11]. These data suggest that host biological or immunological factors that vary with age modify susceptibility to and severity of SARS-CoV-2 infection, and that an understanding of these host factors could inform development of novel strategies to prevent or treat SARS-CoV-2 infections in children and adults.

Given that the upper respiratory microbiome undergoes substantial shifts in early childhood [12-14], and is increasingly recognized to play a key role in the pathogenesis of respiratory virus infections [15-21], we hypothesized that changes in the upper respiratory microbiome with age might contribute to the differences in susceptibility to SARS-CoV-2 infection and the severity of SARS-CoV-2-associated respiratory symptoms among children and adults. In this study, we used 16S ribosomal RNA (rRNA) gene amplicon sequencing to characterize the nasopharyngeal microbiomes of 274 children, adolescents, 
1 between the composition of the nasopharyngeal microbiome and SARS-CoV-2 infection. In addition, we

2 identify bacterial species that are associated with the presence of respiratory symptoms among children

3 with SARS-CoV-2 infection. Finally, we demonstrate that the relative abundances of these bacterial

4 species within the nasopharyngeal microbiome are strongly, and independently, associated with age.

5 Taken together, our findings demonstrate that age-associated changes in the upper respiratory microbiome may contribute to the varied susceptibility to and severity of SARS-CoV-2 infection among children and 7 adults.

METHODS

\section{Study Population}

12 The Duke Biospecimens from RespirAtory Virus-Exposed Kids (BRAVE Kids) study is a prospective cohort study of children, adolescents, and young adults with confirmed SARS-CoV-2 infection or close contact with an individual with confirmed SARS-CoV-2 infection [7]. This study is being conducted within the Duke University Health System in Raleigh-Durham, North Carolina. Eligible participants are less than 21 years of age and have close contact with an individual with SARS-CoV-2 infection confirmed by real-time PCR. Close contact is defined as an unprotected exposure within 6 feet to a confirmed case between 2 days before and 7 days after symptom onset or confirmation of SARS-CoV-2 infection in asymptomatic contacts. Close contacts include, but are not limited to, parents, siblings, other caregivers, and partners.

\section{Study Procedures}

23 We collected exposure, sociodemographic, and clinical data at enrollment through review of electronic 24 medical records and a directed questionnaire conducted by telephone. We recorded any symptoms reported within the 2 weeks preceding study enrollment. In addition, we conducted follow-up 
1 questionnaires for all participants 7 days after study enrollment to document new symptoms and

2 healthcare encounters. For participants with one or more symptoms 7 days after study enrollment,

3 additional questionnaires were administered 14 and 28 days after enrollment, or until the participant

4 reported complete symptom resolution. We recorded the results of SARS-CoV-2 testing performed for

5 clinical care. In addition, we conducted a home visit as soon as possible after study enrollment to collect a nasopharyngeal swab and other biospecimens. Participants who declined a home visit received a kit for self-collection of a mid-turbinate nasal swab. Nasopharyngeal and nasal samples were collected with nylon flocked swabs (Copan Italia, Brescia, Italy) and placed into RNAProtect (Qiagen, Hilden,

Germany) prior to storage at $-80^{\circ} \mathrm{C}$. All nasopharyngeal and nasal samples were tested for SARS-CoV-2 using a real-time quantitative PCR assay, as previously described [7]. We classified participants as SARSCoV-2-infected if SARS-CoV-2 was identified in either a clinical or research PCR assay. We considered SARS-CoV-2-infected individuals as having respiratory symptoms if they reported cough, rhinorrhea, nasal congestion, shortness of breath, sore throat, or anosmia at any point between 14 days prior to enrollment through the end of the study follow-up period. Finally, we classified participants into one of three groups: 1) SARS-CoV-2-uninfected; 2) SARS-CoV-2-infected without respiratory symptoms; and 3) SARS-CoV-2-infected with respiratory symptoms. The analyses presented herein were limited to study participants with an available nasopharyngeal sample.

\section{Processing of nasopharyngeal samples for $16 S$ ribosomal RNA sequencing}

The Duke Microbiome Core Facility extracted DNA from nasopharyngeal samples using Powersoil Pro extraction kits (Qiagen) following the manufacturer's instructions. DNA concentrations were determined using Qubit dsDNA high-sensitivity assay kits (Thermo Fisher Scientific). Bacterial community composition was characterized by PCR amplification of the V4 variable region of the 16S rRNA gene using the forward primer 515 and the reverse primer 806 following the Earth Microbiome Project protocol 
medRxiv preprint doi: https://doi.org/10.1101/2021.03.20.21252680; this version posted March 23, 2021. The copyright holder for this preprint (which was not certified by peer review) is the author/funder, who has granted medRxiv a license to display the preprint in perpetuity.

All rights reserved. No reuse allowed without permission.

1 PCR products from all samples were quantified and pooled prior to sequencing. Sequencing was

2 performed by the Duke Sequencing and Genomic Technologies Core Facility on an Illumina MiSeq

3 instrument configured for 250 base-pair paired-end sequencing. All samples were included in a single

sample processing run with inclusion of both negative extraction and PCR controls. We analyzed raw sequences through a DADA2 pipeline [23] and assigned taxonomy to amplicon sequence variants (ASVs) using Silva SSU version 138 [24]. We identified and removed sequencing contaminants ( $\mathrm{n}=40)$ using the decontam R package [25]. Samples with less than 1000 sequencing reads after quality filtering and contaminant removal were excluded. We obtained a median [interquartile range (IQR)] of 24,422 (17,799, 33,291 ) high-quality sequencing reads from the 274 samples included in these analyses. Sequencing reads were classified into 1,799 ASVs representing 316 bacterial genera from 20 phyla (Supplemental Table 1). We performed standard nucleotide REFSEQ BLAST searches of ASV reference sequences using the National Center for Biotechnology Information's Bacteria and Archaea 16S ribosomal RNA project database [26]. We assigned species information to ASVs using a best-hit approach based on the E value with a minimum percent identity of $99 \%$.

\section{Data Analysis}

We first sought to characterize changes in nasopharyngeal microbiome diversity and composition that occur with age. We calculated nasopharyngeal microbiome alpha (Shannon and Chao1 indices) and beta diversity (Bray-Curtis dissimilarity) using the phyloseq $\mathrm{R}$ package [27]. We then fit linear regression models to evaluate associations between participant age and microbiome alpha diversity measures. The Chao1 index was not normally distributed and was thus log-transformed for these analyses. We then evaluated the association between age and nasopharyngeal microbiome composition with PERMANOVA using the adonis function within the vegan $\mathrm{R}$ package [28]. Finally, we used ANCOM-II [29] to fit linear models evaluating associations between age and the relative abundances of bacterial ASVs within the nasopharyngeal microbiome. An ASV was considered to be differentially abundant if it varied across the 
medRxiv preprint doi: https://doi.org/10.1101/2021.03.20.21252680; this version posted March 23, 2021. The copyright holder for this preprint (which was not certified by peer review) is the author/funder, who has granted medRxiv a license to display the preprint in perpetuity.

All rights reserved. No reuse allowed without permission.

1 independent variable of interest with respect to $80 \%$ of the other ASVs in the dataset ( $W$ statistic $>0.80$ ).

2 ASVs that were identified as structural zeros were not considered to be differentially abundant. All

3 analyses of nasopharyngeal microbiome diversity and composition by age were adjusted for participant

SARS-CoV-2 infection status and the presence of SARS-CoV-2-associated respiratory symptoms. We

then used these same methods to evaluate associations between nasopharyngeal microbiome diversity and composition and SARS-CoV-2 infection status, adjusting for participant age. Finally, in analyses limited

to SARS-CoV-2-infected individuals, we used these same methods to evaluate associations between the

nasopharyngeal microbiome and the presence of respiratory symptoms among SARS-CoV-2-infected

participants, adjusting for age. Our findings were not substantively changed when we additionally

adjusted for sex and race in analyses of nasopharyngeal microbiome diversity and composition by age,

SARS-CoV-2 status, or SARS-CoV-2-associated respiratory symptoms. Given that ANCOM-II produces

only a list of differentially abundant ASVs, we used DESeq2 [30] to generate log2-fold changes in

abundance in order to determine the directionality of these associations. Analyses conducted in ANCOM-

II and DESeq2 were limited to ASVs present in at least 5\% of samples and adjusted for the false

discovery rate using the Benjamini-Hochberg procedure. Analyses were performed using R version 4.0.3

[31] and all visualizations were created using the ggplot2 $\mathrm{R}$ package [32].

\section{RESULTS}

Characteristics of the study population

Two hundred seventy-four children, adolescents, and young adults were included in these analyses (Table

1). Participants were classified as SARS-CoV-2-uninfected $(\mathrm{n}=75,27 \%)$; SARS-CoV-2-infected without

respiratory symptoms $(\mathrm{n}=88,32 \%)$; and SARS-CoV-2-infected with respiratory symptoms $(\mathrm{n}=111,41 \%)$.

Among SARS-CoV-2-infected individuals, nasopharyngeal samples were collected a median (IQR) of 5 
medRxiv preprint doi: https://doi.org/10.1101/2021.03.20.21252680; this version posted March 23, 2021. The copyright holder for this preprint (which was not certified by peer review) is the author/funder, who has granted medRxiv a license to display the preprint in perpetuity.

All rights reserved. No reuse allowed without permission.

1 infected participants with respiratory symptoms were older than SARS-CoV-2-infected participants

2 without respiratory symptoms and SARS-CoV-2-uninfected participants, consistent with our previous

3 observation of a high prevalence of respiratory symptoms among SARS-CoV-2-infected adolescents in

4 this cohort [7]. Similarly, a higher proportion of SARS-CoV-2-infected individuals identified as Latino or

5 Hispanic-American compared to SARS-CoV-2-uninfected individuals [7]. There were no significant

6 differences in the prevalences of comorbidities or recent receipt of antibiotics or probiotics in these 7 groups.

Age-associated changes in nasopharyngeal microbiome composition

10 Median (IQR) Shannon diversity and Chao1 indices of the nasopharyngeal microbiome were 1.49 (1.12, $112.00)$ and $70.0(48.8,97.2)$, respectively. Nasopharyngeal microbiome diversity, as measured by the 12 Shannon diversity index, increased with age (Figure 1a; $\mathrm{p}<0.0001$ ), while nasopharyngeal microbiome 13 richness, as measured by the Chao1 index, declined with increasing age (Figure 1b; $\mathrm{p}=0.02$ ). The 14 composition of the nasopharyngeal microbiome also differed according to age (Figure 1c; PERMANOVA on Bray-Curtis dissimilarity, $\left.\mathrm{p}<0.001, \mathrm{R}^{2}=0.103\right)$. In particular, older age was associated with lower abundances of several ASVs classified as Dolosigranulum, Moraxella, and Streptococcus, and higher abundances of specific ASVs classified as Anaerococcus, Corynebacterium, Lawsonella, Peptoniphilus, and Staphylococcus (Figure 2 and Supplemental Table 2). Infants and young children 5 years of age or younger tended to have high abundances of Dolosigranulum and Moraxella within their nasopharyngeal microbiomes, while the nasopharyngeal microbiomes of adolescents and young adults 12 years of age or older were frequently dominated by Staphylococcus. Additionally, several bacterial genera (Anaerococcus, Lawsonella, and Peptoniphilus) that were of low prevalence and abundance in the nasopharyngeal microbiomes of infants and young children were highly abundant in adolescents and young adults (Supplemental Table 3). Corynebacterium was highly abundant in the nasopharyngeal microbiome across all age categories and its relative abundance was positively correlated with age. 
medRxiv preprint doi: https://doi.org/10.1101/2021.03.20.21252680; this version posted March 23, 2021. The copyright holder for this preprint (which was not certified by peer review) is the author/funder, who has granted medRxiv a license to display the preprint in perpetuity.

All rights reserved. No reuse allowed without permission.

2 Associations between the nasopharyngeal microbiome and SARS-CoV-2 susceptibility

3 Nasopharyngeal microbiome diversity, as measured by the Shannon diversity index, did not differ in

SARS-CoV-2-infected and SARS-CoV-2-uninfected participants (Figure 1a; $\mathrm{p}=0.36$ ). In contrast, SARS-

CoV-2-infected individuals had higher microbiome richness, measured by the log-transformed Chao1 index, than uninfected individuals (Figure 1b; p=0.008). Additionally, nasopharyngeal microbiome composition differed in SARS-CoV-2-infected and uninfected participants (Figure 1c; PERMANOVA on Bray-Curtis dissimilarity, $\left.\mathrm{p}=0.007, \mathrm{R}^{2}=0.009\right)$. In ANCOM-II analyses adjusting for age, we identified two ASVs assigned to the bacterial genus Corynebacterium that were differentially abundant by SARSCoV-2 infection status (Figure 3a and Supplemental Table 4), both of which were of higher abundance in SARS-CoV-2-infected participants relative to uninfected participants. Using BLAST searches, we operationally classified these ASVs as Corynebacterium accolens/macginleyi/tuberculostearicum. Notably, the relative abundances of both of these ASVs increased with increasing age independent of SARS-CoV-2 infection status (Figure 3b and Supplemental Table 2).

\section{Associations between the nasopharyngeal microbiome and SARS-CoV-2-associated respiratory symptoms}

SARS-CoV-2 infection results in a broad range of clinical manifestations from completely asymptomatic to severe pneumonia and acute respiratory distress syndrome [33-35]. In particular, we previously reported marked differences in the prevalences of respiratory symptoms among children, adolescents, and young adults with SARS-CoV-2 infection [7]. To evaluate the extent to which the upper respiratory microbiome contributes to the varied clinical presentations of SARS-CoV-2 infection by age, we compared the nasopharyngeal microbiomes of SARS-CoV-2-infected participants with respiratory symptoms to those of SARS-CoV-2-infected participants without respiratory symptoms. Nasopharyngeal microbiome alpha diversity (Shannon diversity, Chao1 richness) was similar in SARS-CoV-2-infected individuals with or without respiratory symptoms (Figure 1a and Figure 1b), while nasopharyngeal 
medRxiv preprint doi: https://doi.org/10.1101/2021.03.20.21252680; this version posted March 23, 2021. The copyright holder for this preprint (which was not certified by peer review) is the author/funder, who has granted medRxiv a license to display the preprint in perpetuity.

All rights reserved. No reuse allowed without permission.

1 microbiome composition differed between these groups (Figure 1c; PERMANOVA on Bray-Curtis

2 dissimilarity, $\left.\mathrm{p}=0.008, \mathrm{R}^{2}=0.014\right)$. In ANCOM-II analyses adjusting for age, we identified nine ASVs that

3 were differentially abundant in SARS-CoV-2-infected participants with or without respiratory symptoms

4 (Figure 4a and Supplemental Table 5). The two ASVs classified as Corynebacterium that were

5 associated with SARS-CoV-2 infection status (ASV 1017, ASV 1030) were also more abundant in SARS-

6 CoV-2-infected individuals with respiratory symptoms compared to SARS-CoV-2-infected individuals

7 without respiratory symptoms. Additionally, two other Corynebacterium ASVs that were identified as

8 Corynebacterium accolens/macginleyi/tuberculostearicum (ASV 1014, ASV 1032) were more abundant

9 in SARS-CoV-2-infected participants with respiratory symptoms. Other ASVs that were more abundant in

10 SARS-CoV-2-infected participants with respiratory symptoms were classified as Lawsonella

11 clevelandensis (ASV 1060), Finegoldia magna (ASV 1535), Anaerococcus spp. (ASV 1593) and

12 Peptononiphilus spp. (ASV 1618). Each of the ASVs that were associated with the presence of respiratory

13 symptoms in SARS-CoV-2-infected individuals were independently and positively associated with

14 increasing age (Figure $\mathbf{4 b}$ and Supplemental Table 2), with several ASVs that were almost exclusively

15 detected in adolescents 12 years of age or older. We also identified a single ASV that was assigned to

16 Dolosigranulum pigrum (ASV 1491) that was of lower abundance in SARS-CoV-2-infected participants

17 with respiratory symptoms and additionally declined in abundance with increasing age. Finally,

18 nasopharyngeal microbiome composition also differed between SARS-CoV-2-infected participants with

19 respiratory symptoms and SARS-CoV-2-uninfected participants (PERMANOVA on Bray-Curtis

20 dissimilarity, $\mathrm{p}<0.001, \mathrm{R}^{2}=0.015$ ), with several of these same Corynebacterium ASVs (ASV 1017, ASV

21 1030, ASV 1032) and ASVs classified as Anaerococcus spp. (ASV 1582) and Peptoniphilus spp. (ASV

22 1618) being more abundant in the nasopharyngeal microbiomes of SARS-CoV-2-infected participants

23 with respiratory symptoms (Supplemental Table 6). 
medRxiv preprint doi: https://doi.org/10.1101/2021.03.20.21252680; this version posted March 23, 2021. The copyright holder for this preprint (which was not certified by peer review) is the author/funder, who has granted medRxiv a license to display the preprint in perpetuity.

All rights reserved. No reuse allowed without permission.

2 In this study, we found that higher abundances of specific Corynebacterium ASVs are associated with

3 SARS-CoV-2 infection among children, adolescents, and young adults with a SARS-CoV-2-infected

4 close contact. In addition, we identified nasopharyngeal microbiome alterations, including higher

5 abundances of Corynebacterium and lower abundances of D. pigrum, that are associated with the

6 presence of respiratory symptoms in the setting of confirmed SARS-CoV-2 infection. Finally, we

7 demonstrate that these same microbiome features are strongly, and independently, associated with

8 increasing age. Our findings suggest that the upper respiratory microbiome may be a previously

9 unrecognized and potentially modifiable mechanism by which age influences SARS-CoV-2 susceptibility

10 and illness severity.

12 Over the past several decades, accumulating data have emerged demonstrating that the upper respiratory 13 microbiome plays a key role in the pathogenesis of respiratory virus infections. First, several studies 14 indicate that the upper respiratory microbiome modifies susceptibility to respiratory virus infections, as 15 has been most clearly demonstrated for influenza viruses through household transmission studies [15, 16]. 16 Among 436 household contacts in one of these studies, higher abundances of Streptococcus spp. and 17 Prevotella salivae within the nasal/oropharyngeal microbiome were associated with lower susceptibility to influenza A infection [15]. Additionally, the upper respiratory microbiome may also influence the symptoms experienced by individuals when respiratory virus infection does occur, presumably through modulation of the host immune response [36]. For instance, the nasopharyngeal microbiome appears to modify the severity of respiratory syncytial virus (RSV) infection among young children, with several studies reporting that higher abundances of Haemophilus species are associated with a more exuberant host immune response to RSV [17-19]. Nasopharyngeal microbiome profiles are also associated with the

24 levels of inflammatory cytokines in nasal wash samples and the development of symptomatic infection in 
medRxiv preprint doi: https://doi.org/10.1101/2021.03.20.21252680; this version posted March 23, 2021. The copyright holder for this preprint (which was not certified by peer review) is the author/funder, who has granted medRxiv a license to display the preprint in perpetuity.

All rights reserved. No reuse allowed without permission.

1 live bacterial strains has been shown to directly modulate immune responses to influenza viruses and RSV

2 in animal models [37-40]. While data from clinical studies are currently lacking, this work illustrates the

3 potential that targeted manipulation of the upper respiratory microbiome holds for the prevention and

4 treatment of respiratory virus infections.

5

6

To date, studies of the upper respiratory microbiome and SARS-CoV-2 infection have been conducted among small cohorts of adults presenting with clinical suspicion of COVID-19. De Maio and colleagues did not find any differences in the nasopharyngeal microbiomes of 18 individuals with symptomatic SARS-CoV-2 infection and 22 individuals with acute respiratory symptoms who tested negative for SARS-CoV-2 [41]. Conversely, a study of 59 adults identified several ASVs that were differentially abundant in those with SARS-CoV-2 infection and in those with higher viral loads during COVID-19, including higher abundances of ASVs classified as Peptoniphilus lacrimalis, Prevotella copri, and Anaerococcus spp. [42]. By comparison, Mostafa and colleagues reported lower nasopharyngeal microbial diversity, a lower abundance of the bacterial family Propionibacteriaceae, and a higher abundance of Corynebacterium accolens in 40 SARS-CoV-2-infected adults compared to 10 SARS-CoV2-uninfected adults with suspected COVID-19 [43]. Consistent with findings from this latter study, and in the largest cohort studied to date, here we demonstrated that ASVs assigned to Corynebacterium spp. (C. accolens/macginleyi/tuberculostearicum) were associated with SARS-CoV-2 infection among 274 children, adolescents, and adults with SARS-CoV-2 exposure. In addition, we identified novel associations between ASVs assigned to Corynebacterium spp., Lawsonella clevelandensis, Finegoldia magna, Anaerococcus spp., Peptoniphilus spp., and Dolosigranulum pigrum and the presence of respiratory symptoms during SARS-CoV-2 infection. Notably, the changes in relative abundances of these ASVs that were associated with SARS-CoV-2 infection and SARS-CoV-2-associated respiratory symptoms were also independently associated with increasing age, suggesting that age-associated changes 
medRxiv preprint doi: https://doi.org/10.1101/2021.03.20.21252680; this version posted March 23, 2021. The copyright holder for this preprint (which was not certified by peer review) is the author/funder, who has granted medRxiv a license to display the preprint in perpetuity.

All rights reserved. No reuse allowed without permission.

1 in the upper respiratory microbiome may underlie the differences in SARS-CoV-2 susceptibility and

2 illness severity that exist between children and adults.

4 Non-diphtheriae Corynebacterium species and D. pigrum were previously shown to have important

5 microbial interactions within the human nasopharynx. In particular, the abundance of Corynebacterium within the nasopharyngeal microbiome has been negatively associated with colonization by Streptococcus pneumoniae among infants and children [44-47], while the relative abundance of $D$. pigrum within the nasopharyngeal microbiome has been negatively associated with the co-occurrence of both S. pneumoniae and $S$. aureus $[47,48]$. Few prior clinical studies identified associations between these bacterial species and the risk and severity of respiratory virus infections. Interestingly, strains of Corynebacterium spp. and D. pigrum have been shown to influence innate immune responses to influenza and RSV in murine models [49-51], suggesting that these bacterial commensals may influence overall immunological tone within the upper respiratory tract. Importantly, much of the work on these bacterial species has been conducted in young children [44-48], and surprisingly little is known about the abundances and functions of these microbes in the upper respiratory tracts of adults. Taken together, these studies suggest that specific strains of commensal bacteria have differential impacts on host immune responses to potential pathogens and that age-associated changes in the relative abundance of different species likely plays a critical role in infection susceptibility.

Previous studies demonstrated that the nasopharyngeal microbiome is a relatively low-diversity ecological niche in young children and older adults. Importantly, relatively few bacterial genera comprise the majority of the nasopharyngeal microbiome during infancy and early childhood, with microbiome composition being influenced by breastfeeding [14, 52], mode of delivery [53, 54], acute respiratory infections [12], antibiotic treatment [12], and season [55]. Studies of older children and adolescents have 
medRxiv preprint doi: https://doi.org/10.1101/2021.03.20.21252680; this version posted March 23, 2021. The copyright holder for this preprint (which was not certified by peer review) is the author/funder, who has granted medRxiv a license to display the preprint in perpetuity.

All rights reserved. No reuse allowed without permission.

1 respiratory diseases [56-59]. Pérez-Losada and colleagues profiled the nasopharyngeal microbiomes of 40

2 children and adolescents 6-17 years of age with asthma, and found that the most abundant genera were

3 Moraxella, Staphylococcus, Dolosigranulum, Corynebacterium, Prevotella, and Streptococcus [60].

4 Several of these bacterial genera are reported to be highly abundant in the nasopharyngeal microbiomes of

5 healthy adults and adults with asthma $[61,62]$. To our knowledge, there are no prior studies that evaluated

upper respiratory microbiome profiles from infancy through early adulthood. Our findings demonstrate

that the nasopharyngeal microbiome continues to develop throughout childhood and adolescence. Future studies should investigate the biological or environmental factors that contribute to the shifts in microbiome composition that occur after early childhood.

Our study had several limitations. First, nasopharyngeal samples were collected at a single time point, and we did not have nasopharyngeal samples prior to infection in SARS-CoV-2-infected participants. Therefore, we were unable to determine if the differences in nasopharyngeal microbiome composition observed by SARS-CoV-2 infection status preceded, or were the consequence of, SARS-CoV-2 infection. Secondly, all of the SARS-CoV-2-infected study participants had relatively mild symptoms, and no study participants required antiviral treatment or hospitalization. We therefore were unable to evaluate if the microbiome features that we identified as being associated with SARS-CoV-2 respiratory symptoms are additionally associated with severe COVID-19. In addition, our use of 16S rRNA gene amplicon sequencing prevented us from evaluating other components of the upper respiratory microbiome, including viruses and fungi. Additionally, 16S rRNA gene amplicon experiments have several welldocumented biases [63], although we sought to minimize these biases in our study through inclusion of all samples in a single processing run and use of appropriate negative controls. Finally, although analyses adjusted for age in evaluating associations between the nasopharyngeal microbiome and SARS-CoV-2 susceptibility and illness severity, residual confounding by unmeasured factors remains possible. 
medRxiv preprint doi: https://doi.org/10.1101/2021.03.20.21252680; this version posted March 23, 2021. The copyright holder for this preprint (which was not certified by peer review) is the author/funder, who has granted medRxiv a license to display the preprint in perpetuity.

All rights reserved. No reuse allowed without permission.

1 In conclusion, we found that age-associated changes in the nasopharyngeal microbiome are independently

2 associated with SARS-CoV-2 infection and SARS-CoV-2-associated respiratory symptoms among

3 children, adolescents, and young adults. These findings suggest that development of the nasopharyngeal

4 microbiome during childhood and adolescence may contribute to the differences in SARS-CoV-2

5 susceptibility and severity observed by age. Future studies should evaluate the potential of the upper

6 respiratory microbiome to serve as a therapeutic target for the prevention and treatment of infections

7 caused by SARS-CoV-2 and other respiratory viruses. 
medRxiv preprint doi: https://doi.org/10.1101/2021.03.20.21252680; this version posted March 23, 2021. The copyright holder for this preprint (which was not certified by peer review) is the author/funder, who has granted medRxiv a license to display the preprint in perpetuity.

All rights reserved. No reuse allowed without permission.

\section{ACKNOWLEDGEMENTS}

3 We would like to thank the Duke University School of Medicine for use of the Microbiome Core Facility,

4 which performed the DNA extractions and library preparations for this research, and the Duke

5 Sequencing and Genomic Technologies Core Facility, which sequenced these libraries. We offer our 6 sincere gratitude to the children and families who participated in this research.

\section{DECLARATIONS}

\section{Ethics approval and consent to participate}

11 This study was approved by the Duke University Health System Institutional Review Board. Written 12 informed consent was obtained from all participants or their legal guardian.

\section{Availability of data and materials}

15 The sequencing dataset supporting the conclusions of this study is available in the Sequence Read Archive (PRJNA703574). The statistical files and script used for data analyses are also publicly available (https://github.com/alexmccumber/BRAVE_Kids).

\section{Competing Interests}

MSK reports advisory board feeds from Adagio Therapeutics, Inc. CWW reports advisory board fees from Roche Molecular Sciences, non-financial support from bioMérieux and Becton Dickinson, a research collaboration with Biofire, and is co-founder of Predigen. All other authors have no competing interests to declare. 
medRxiv preprint doi: https://doi.org/10.1101/2021.03.20.21252680; this version posted March 23, 2021. The copyright holder for this preprint (which was not certified by peer review) is the author/funder, who has granted medRxiv a license to display the preprint in perpetuity.

All rights reserved. No reuse allowed without permission.

\section{$1 \quad$ Funding}

2 This work was funded by the Duke University School of Medicine and through grants from the Duke

3 Microbiome Center, Children's Miracle Network Hospitals, and the Translating Duke Health Children's

4 Health and Discovery Initiative. AWM was supported by a grant from the National Science Foundation

5 (DGE-1545220). SMH was supported by National Institutes of Health (NIH) training grant (T32-

6 HD094671). MSK was supported by a NIH Career Development Award (K23-AI135090).

8 Author contributions

9 JHH, AWM, SMH, MAM, JFR, CWW, and MSK contributed to the study concept and design. JNA, JR,

10 DJL, ATR, NAT, TSP, TCG, and TND collected the data or assisted with data analysis or interpretation.

$11 \mathrm{JHH}, \mathrm{AWM}$, and MSK drafted the manuscript and all other authors revised it critically for important

12 intellectual content. All authors approved of the final version of the manuscript. 
medRxiv preprint doi: https://doi.org/10.1101/2021.03.20.21252680; this version posted March 23, 2021. The copyright holder for this preprint (which was not certified by peer review) is the author/funder, who has granted medRxiv a license to display the preprint in perpetuity.

All rights reserved. No reuse allowed without permission.

\section{REFERENCES}

1. Dong E, Du H, Gardner L. An interactive web-based dashboard to track COVID-19 in real time. Lancet Infect Dis; published online Feb 19. https://doi.org/10.1016/S1473-3099(20)30120-1.

2. Welliver, R.C., Review of epidemiology and clinical risk factors for severe respiratory syncytial virus (RSV) infection. The Journal of pediatrics, 2003. 143(5): p. 112-117.

3. Laurichesse, H., et al., Epidemiological features of parainfluenza virus infections: laboratory surveillance in England and Wales, 1975-1997. European journal of epidemiology, 1999. 15(5): p. $475-484$.

4. Piotrowska, Z., et al., Rhinoviruses are a major cause of wheezing and hospitalization in children less than 2 years of age. The Pediatric infectious disease journal, 2009. 28(1): p. 25.

5. Viner, R.M., et al., Susceptibility to SARS-CoV-2 Infection Among Children and Adolescents Compared With Adults: A Systematic Review and Meta-analysis. JAMA Pediatrics, 2021. 175(2):

6. COVID-19 Stats: COVID-19 Incidence, by Age Group - United States, March 1-November 14, 2020. MMWR Morb Mortal Wkly Rep 2021;69:1664. doi: http://dx.doi.org/10.15585/mmwr.mm695152a8.

7. Hurst, J.H., et al., SARS-CoV-2 Infections Among Children in the Biospecimens from Respiratory Virus-Exposed Kids (BRAVE Kids) Study. Clin Infect Dis, 2020.

8. $\quad$ Castagnoli, R., et al., Severe Acute Respiratory Syndrome Coronavirus 2 (SARS-CoV-2) Infection in Children and Adolescents: A Systematic Review. JAMA Pediatrics, 2020. 174(9): p. 882-889.

9. Yousaf, A.R., et al., A prospective cohort study in non-hospitalized household contacts with SARSCoV-2 infection: symptom profiles and symptom change over time. Clin Infect Dis, 2020.

10. Han, M.S., et al., Clinical Characteristics and Viral RNA Detection in Children With Coronavirus Disease 2019 in the Republic of Korea. JAMA Pediatr, 2021. 175(1): p. 73-80. 
medRxiv preprint doi: https://doi.org/10.1101/2021.03.20.21252680; this version posted March 23, 2021. The copyright holder for this preprint (which was not certified by peer review) is the author/funder, who has granted medRxiv a license to display the preprint in perpetuity.

All rights reserved. No reuse allowed without permission.

1 11. Kim, L., et al., Hospitalization Rates and Characteristics of Children Aged <18 Years Hospitalized with Laboratory-Confirmed COVID-19 - COVID-NET, 14 States, March 1-July 25, 2020. MMWR Morb Mortal Wkly Rep, 2020. 69(32): p. 1081-1088.

12. Teo, S.M., et al., The infant nasopharyngeal microbiome impacts severity of lower respiratory infection and risk of asthma development. Cell host \& microbe, 2015. 17(5): p. 704-715.

13. Mika, M., et al., Dynamics of the nasal microbiota in infancy: A prospective cohort study. Journal of Allergy and Clinical Immunology, 2015. 135(4): p. 905-912. e11.

14. Biesbroek, G., et al., Early respiratory microbiota composition determines bacterial succession

15. Tsang, T.K., et al., Association between the respiratory microbiome and susceptibility to influenza

16. Lee, K.H., et al., The respiratory microbiome and susceptibility to influenza virus infection. PLOS ONE, 2019. 14(1): p. e0207898.

17. Chu, C.-Y., et al., Airway Gene Expression Correlates of Respiratory Syncytial Virus Disease Severity and Microbiome Composition in Infants. The Journal of Infectious Diseases, 2020.

18. Ederveen, T.H., et al., Haemophilus is overrepresented in the nasopharynx of infants hospitalized with RSV infection and associated with increased viral load and enhanced mucosal CXCL8 responses. Microbiome, 2018. 6(1): p. 1-13.

19. de Steenhuijsen Piters, W.A., et al., Nasopharyngeal Microbiota, Host Transcriptome and Disease Severity in Children with Respiratory Syncytial Virus Infection. American journal of respiratory and critical care medicine, 2016(ja).

20. Lehtinen, M.J., et al., Nasal microbiota clusters associate with inflammatory response, viral load, and symptom severity in experimental rhinovirus challenge. Scientific Reports, 2018. 8(1): p. 
medRxiv preprint doi: https://doi.org/10.1101/2021.03.20.21252680; this version posted March 23, 2021. The copyright holder for this preprint (which was not certified by peer review) is the author/funder, who has granted medRxiv a license to display the preprint in perpetuity.

All rights reserved. No reuse allowed without permission.

1 21. Allen, E.K., et al., Characterization of the nasopharyngeal microbiota in health and during rhinovirus challenge. Microbiome, 2014. 2(1): p. 22.

3 22. Gilbert, J.A., et al., Meeting report: the terabase metagenomics workshop and the vision of an Earth microbiome project. Stand Genomic Sci, 2010. 3(3): p. 243-8.

23. Callahan, B.J., et al., DADA2: high-resolution sample inference from Illumina amplicon data. Nature methods, 2016. 13(7): p. 581.

24. McLaren MR. Silva SSU taxonomic training data formatted for DADA2 (Silva version 138), 2020. Available at: http://doi.org/10.5281/zenodo.3986799.

25. Davis, N.M., et al., Simple statistical identification and removal of contaminant sequences in marker-gene and metagenomics data. Microbiome, 2018. 6(1): p. 226.

26. Camacho, C., et al., BLAST+: architecture and applications. BMC Bioinformatics, 2009. 10: p. 421.

27. McMurdie, P.J. and S. Holmes, phyloseq: an R package for reproducible interactive analysis and

28. Oksanen, J., et al., The vegan package. Community ecology package, 2007. 10(631-637): p. 719.

29. Kaul, A., et al., Analysis of microbiome data in the presence of excess zeros. Frontiers in

30. Love, M.I., W. Huber, and S. Anders, Moderated estimation of fold change and dispersion for microbiology, 2017. 8: p. 2114.

31. $\quad R$ Core Team (2019). $R$ : A language and environment for statistical computing. $R$ Foundation for Statistical Computing, Vienna, Austria. URL https://www.R-project.org/.

32. H. Wickham. ggplot2: Elegant Graphics for Data Analysis. Springer-Verlag New York, 2016.

33. He, X., et al., Clinical Symptom Differences Between Mild and Severe COVID-19 Patients in China: A Meta-Analysis. Front Public Health, 2020. 8: p. 561264. 
medRxiv preprint doi: https://doi.org/10.1101/2021.03.20.21252680; this version posted March 23, 2021. The copyright holder for this preprint (which was not certified by peer review) is the author/funder, who has granted medRxiv a license to display the preprint in perpetuity.

All rights reserved. No reuse allowed without permission.

1 34. Zhu, J., et al., Clinical characteristics of 3062 COVID-19 patients: A meta-analysis. J Med Virol, 2020. 92(10): p. 1902-1914.

3 35. Tenforde, M.W., et al., Characteristics of adult outpatients and inpatients with COVID-19-11 academic medical centers, United States, March-May 2020. Morbidity and Mortality Weekly Report, 2020. 69(26): p. 841.

36. Pichon, M., B. Lina, and L. Josset, Impact of the respiratory microbiome on host responses to respiratory viral infection. Vaccines, 2017. 5(4): p. 40.

38. Zelaya, H., et al., Nasal priming with immunobiotic Lactobacillus rhamnosus modulates inflammation-coagulation interactions and reduces influenza virus-associated pulmonary

43. Mostafa, H.H., et al., Metagenomic next-generation sequencing of nasopharyngeal specimens 
medRxiv preprint doi: https://doi.org/10.1101/2021.03.20.21252680; this version posted March 23, 2021. The copyright holder for this preprint (which was not certified by peer review) is the author/funder, who has granted medRxiv a license to display the preprint in perpetuity.

All rights reserved. No reuse allowed without permission.

1 44. Kelly, M.S., et al., The nasopharyngeal microbiota of children with respiratory infections in Botswana. The Pediatric infectious disease journal, 2017. 36(9): p. e211.

45. Bomar, L., et al., Corynebacterium accolens releases antipneumococcal free fatty acids from human nostril and skin surface triacylglycerols. MBio, 2016. 7(1): p. e01725-15.

46. Khamash, D.F., et al., The Association Between the Developing Nasal Microbiota of Hospitalized Neonates and Staphylococcus aureus Colonization. Open Forum Infectious Diseases, 2019. 6(4).

47. Laufer, A.S., et al., Microbial communities of the upper respiratory tract and otitis media in children. MBio, 2011. 2(1): p. e00245-10.

48. Brugger, S.D., et al., Dolosigranulum pigrum cooperation and competition in human nasal microbiota. Msphere, 2020. 5(5).

49. Ortiz Moyano, R., et al., The ability of respiratory commensal bacteria to beneficially modulate the lung innate immune response is a strain dependent characteristic. Microorganisms, 2020.

50. Kanmani, P., et al., Respiratory commensal bacteria Corynebacterium pseudodiphtheriticum

53. Bosch, A.A., et al., Development of upper respiratory tract microbiota in infancy is affected by 
medRxiv preprint doi: https://doi.org/10.1101/2021.03.20.21252680; this version posted March 23, 2021. The copyright holder for this preprint (which was not certified by peer review) is the author/funder, who has granted medRxiv a license to display the preprint in perpetuity.

All rights reserved. No reuse allowed without permission.

1 54. Dominguez-Bello, M.G., et al., Delivery mode shapes the acquisition and structure of the initial microbiota across multiple body habitats in newborns. Proceedings of the National Academy of Sciences, 2010. 107(26): p. 11971-11975.

55. Bogaert, D., et al., Variability and diversity of nasopharyngeal microbiota in children: a metagenomic analysis. Plos one, 2011. 6(2): p. e17035.

56. Hilty, M., et al., Disordered microbial communities in asthmatic airways. PloS one, 2010. 5(1): p. e8578.

57. Marri, P.R., et al., Asthma-associated differences in microbial composition of induced sputum. Journal of Allergy and Clinical Immunology, 2013. 131(2): p. 346-352. e3.

58. Zhang, Q., et al., Airway microbiota in severe asthma and relationship to asthma severity and phenotypes. PloS one, 2016. 11(4): p. e0152724.

59. Hahn, A., et al., Microbial diversity within the airway microbiome in chronic pediatric lung diseases. Infection, Genetics and Evolution, 2018. 63: p. 316-325.

60. Pérez-Losada, M., et al., Nasopharyngeal Microbiome Diversity Changes over Time in Children with Asthma. PLoS One, 2017. 12(1): p. e0170543.

61. Stearns, J.C., et al., Culture and molecular-based profiles show shifts in bacterial communities of

62. Bomar, L., S.D. Brugger, and K.P. Lemon, Bacterial microbiota of the nasal passages across the span of human life. Current opinion in microbiology, 2018. 41: p. 8-14.

63. Brooks, J.P., et al., The truth about metagenomics: quantifying and counteracting bias in 16S rRNA studies. BMC Microbiology, 2015. 15(1): p. 66. 
medRxiv preprint doi: https://doi.org/10.1101/2021.03.20.21252680; this version posted March 23, 2021. The copyright holder for this preprint (which was not certified by peer review) is the author/funder, who has granted medRxiv a license to display the preprint in perpetuity. All rights reserved. No reuse allowed without permission.

\section{FIGURES}

a

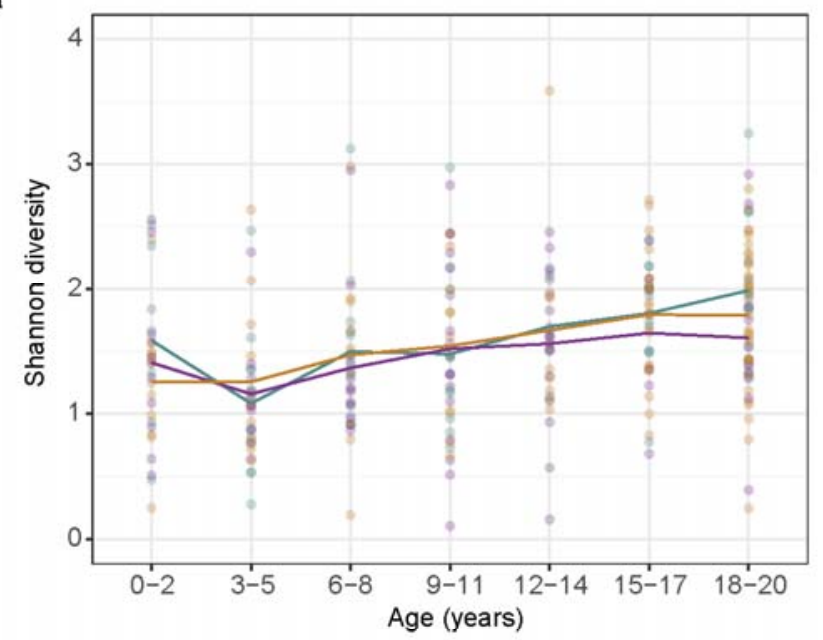

C

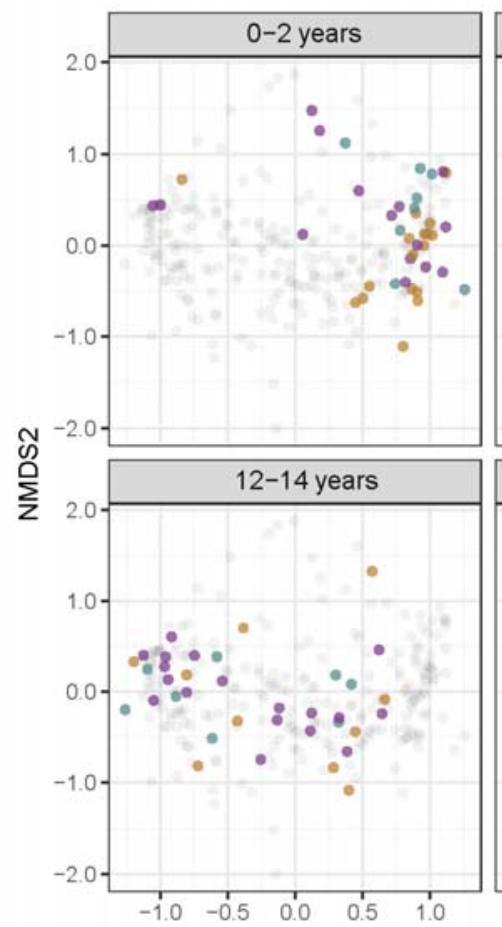

b
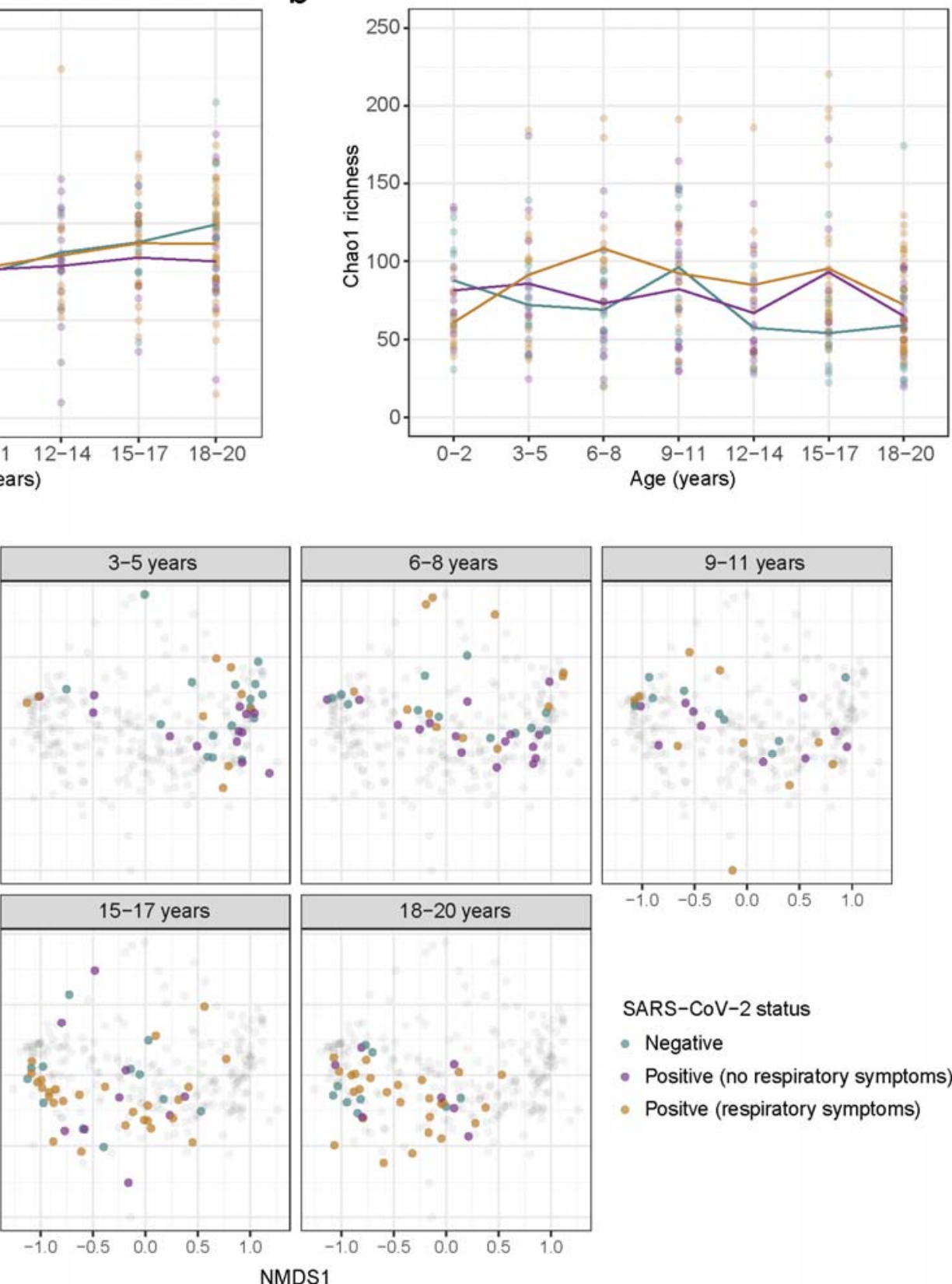

Figure 1. Nasopharyngeal microbiome alpha and beta diversity by age and SARS-CoV-2 clinical

status. Shannon diversity (a) and Chao1 richness (b) is shown for each age group by clinical status:

SARS-CoV-2-uninfected (green), SARS-CoV-2-infected without respiratory symptoms (purple), and

SARS-CoV-2-infected with respiratory symptoms (orange). Points represent individual samples while the

7 line denotes means for samples from each group in each age category. (c) Non-metric multidimensional

scaling plot based on Bray-Curtis distances is shown by age category and according to SARS-CoV-2 
medRxiv preprint doi: https://doi.org/10.1101/2021.03.20.21252680; this version posted March 23, 2021. The copyright holder for this preprint (which was not certified by peer review) is the author/funder, who has granted medRxiv a license to display the preprint in perpetuity. All rights reserved. No reuse allowed without permission.

1 clinical status [(SARS-CoV-2-uninfected (green), SARS-CoV-2-infected without respiratory symptoms

2 (purple), and SARS-CoV-2-infected with respiratory symptoms (orange)]. Within each panel 3 corresponding to an age category, the colored points represent samples for the corresponding age 4 category, while the gray points represent samples collected from children in other age categories. 


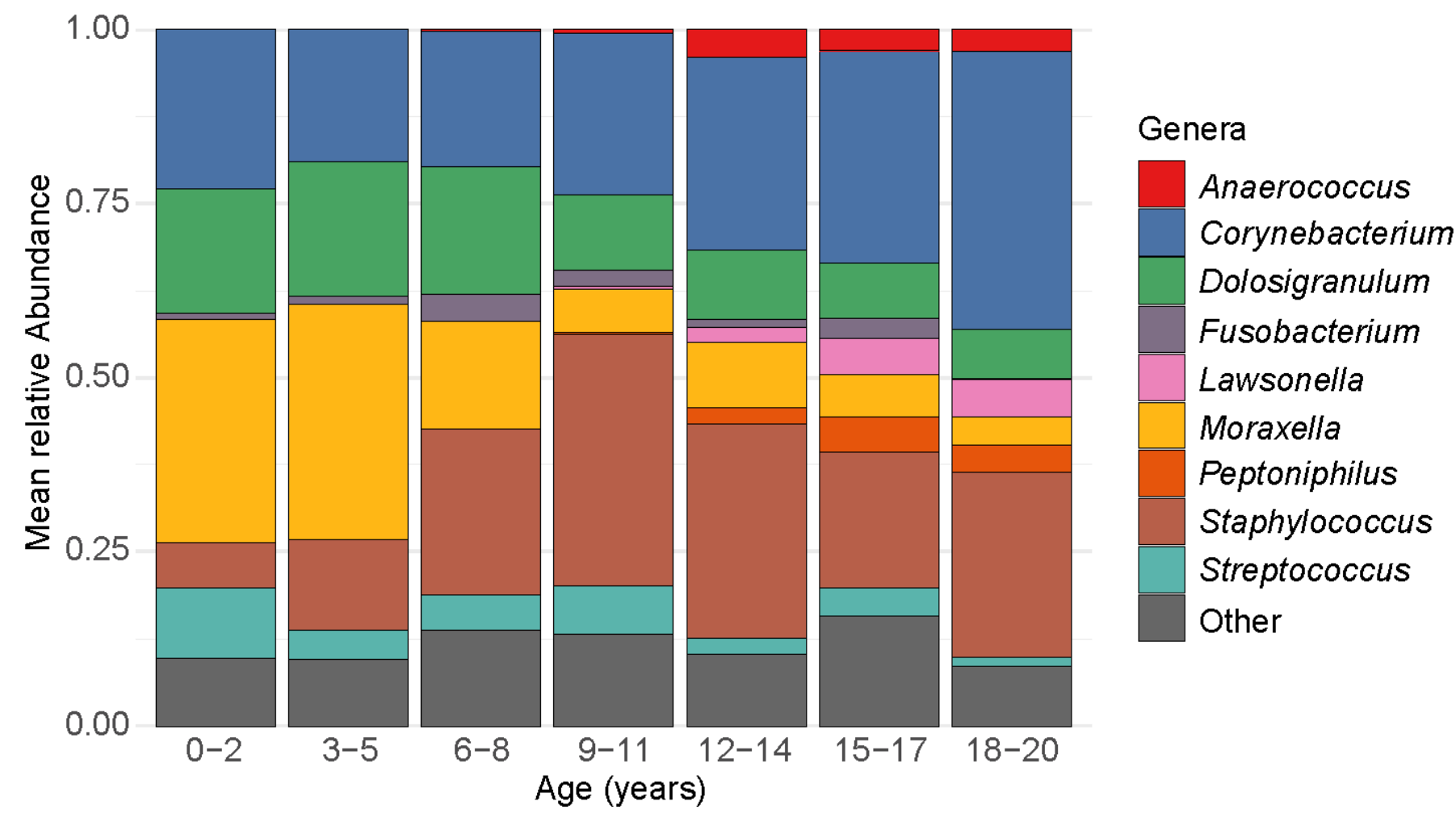

2 Figure 2. Relative abundances of highly abundant genera by age. Each bar depicts the mean relative

3 abundances of highly abundant genera in nasopharyngeal samples from participants in a specific age

4 category. Only the nine most highly abundant genera within nasopharyngeal samples from the entire 5 study population are shown. 
medRxiv preprint doi: https://doi.org/10.1101/2021.03.20.21252680; this version posted March 23, 2021. The copyright holder for this preprint (which was not certified by peer review) is the author/funder, who has granted medRxiv a license to display the preprint in perpetuity.

All rights reserved. No reuse allowed without permission.

a

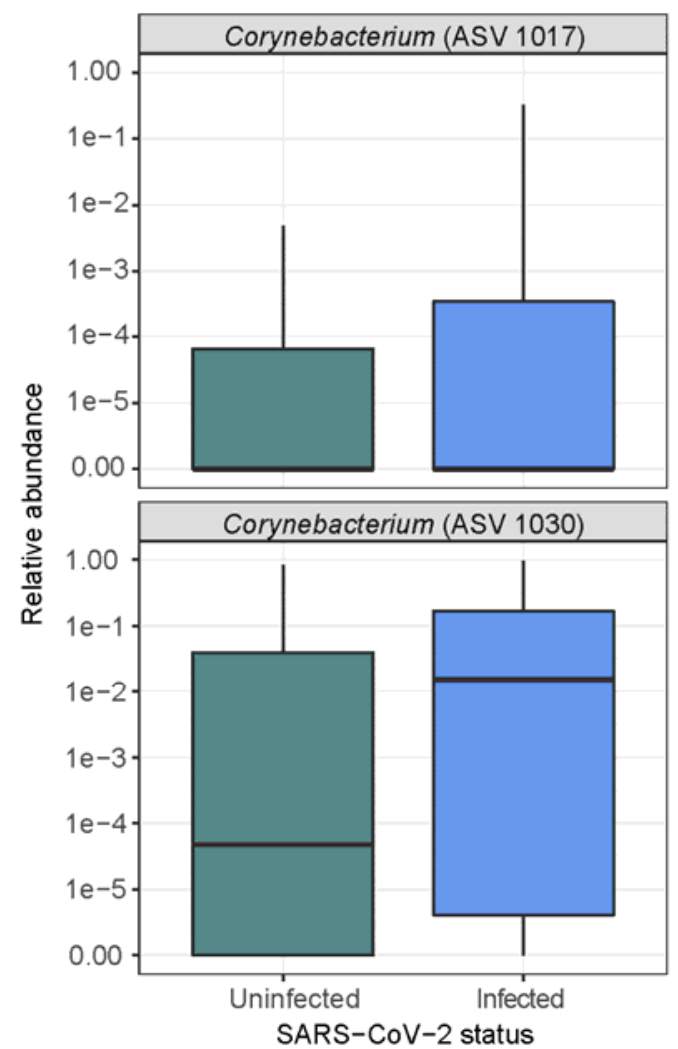

b

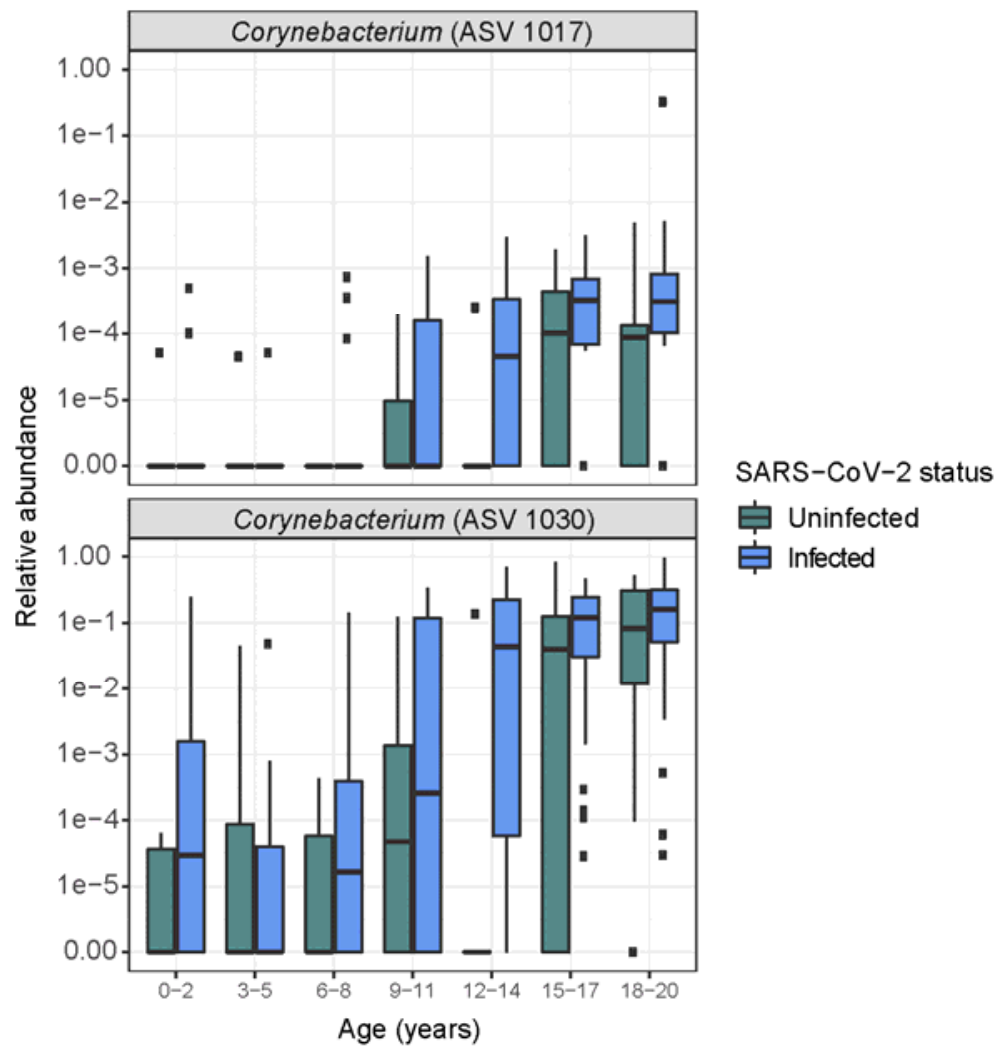

Figure 3. Relative abundances of ASVs that were differentially abundant by SARS-CoV-2 infection

status. a) Boxplots of the relative abundances of ASVs that were differentially abundant by SARS-CoV-2

4 infection status in age-adjusted analyses conducted in ANCOM-II. a) Boxplots of the relative abundances

5 by age group of ASVs that were differentially abundant by SARS-CoV-2 infection status in age-adjusted

6 analyses conducted in ANCOM-II. Relative abundances are plotted on a log scale with 1E-6 added to all

7 counts to enable transformation of zero counts. Rectangles represent the lower quartile, median, and upper

8 quartile of the relative abundances of each ASV. The relative abundances of two ASVs classified as

9 Corynebacterium accolens/macginleyi/tuberculostearicum were higher in SARS-CoV-2-infected individuals compared to uninfected individuals, adjusting for age (ASV 1017, W=192; ASV 1030,

$11 W=233$ ). In addition, the relative abundances of these Corynebacterium ASVs increased with increasing 12 age adjusting for SARS-CoV-2 infection status and the presence of SARS-CoV-2-associated respiratory symptoms (ASV 1017, W=170; ASV 1030, W=173). 
medRxiv preprint doi: https://doi.org/10.1101/2021.03.20.21252680; this version posted March 23, 2021. The copyright holder for this preprint (which was not certified by peer review) is the author/funder, who has granted medRxiv a license to display the preprint in perpetuity.

All rights reserved. No reuse allowed without permission.

a
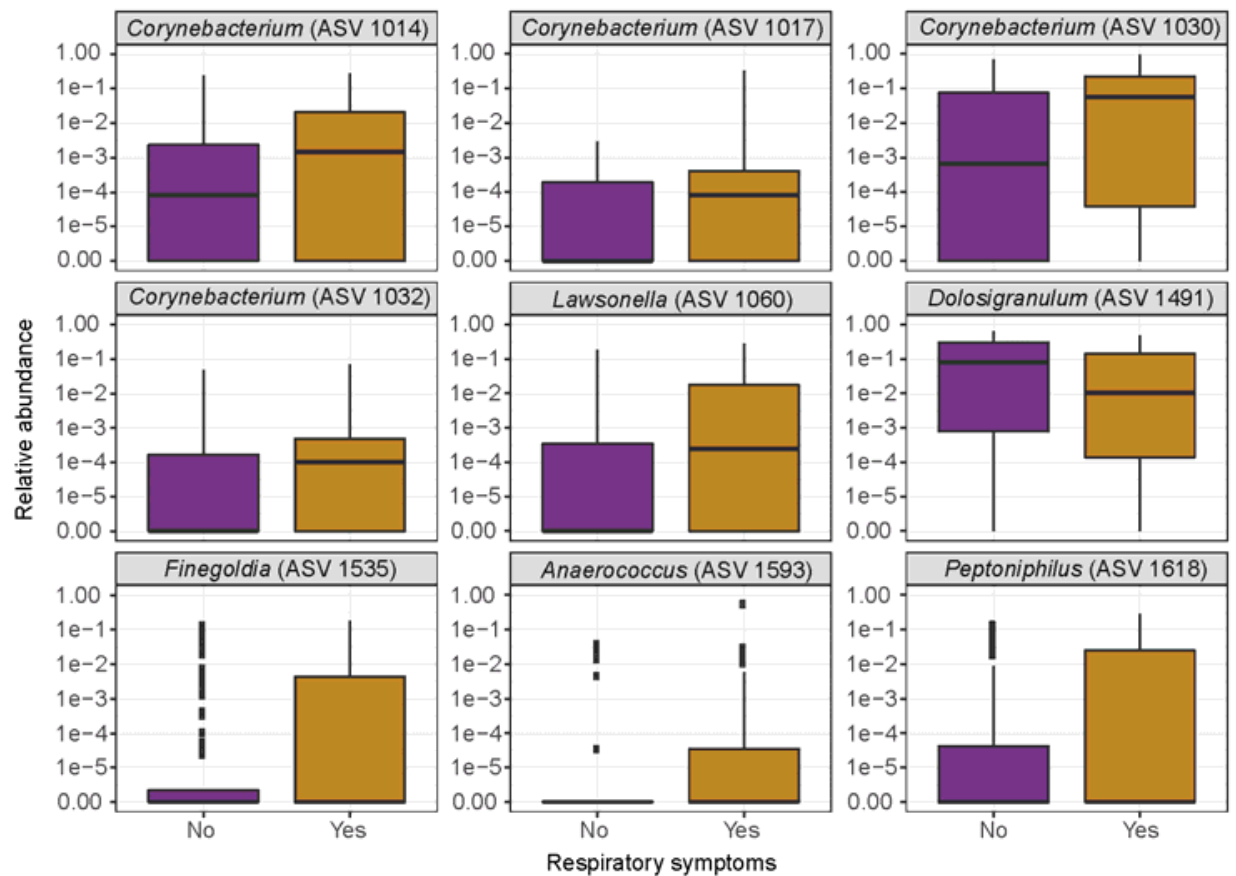

b
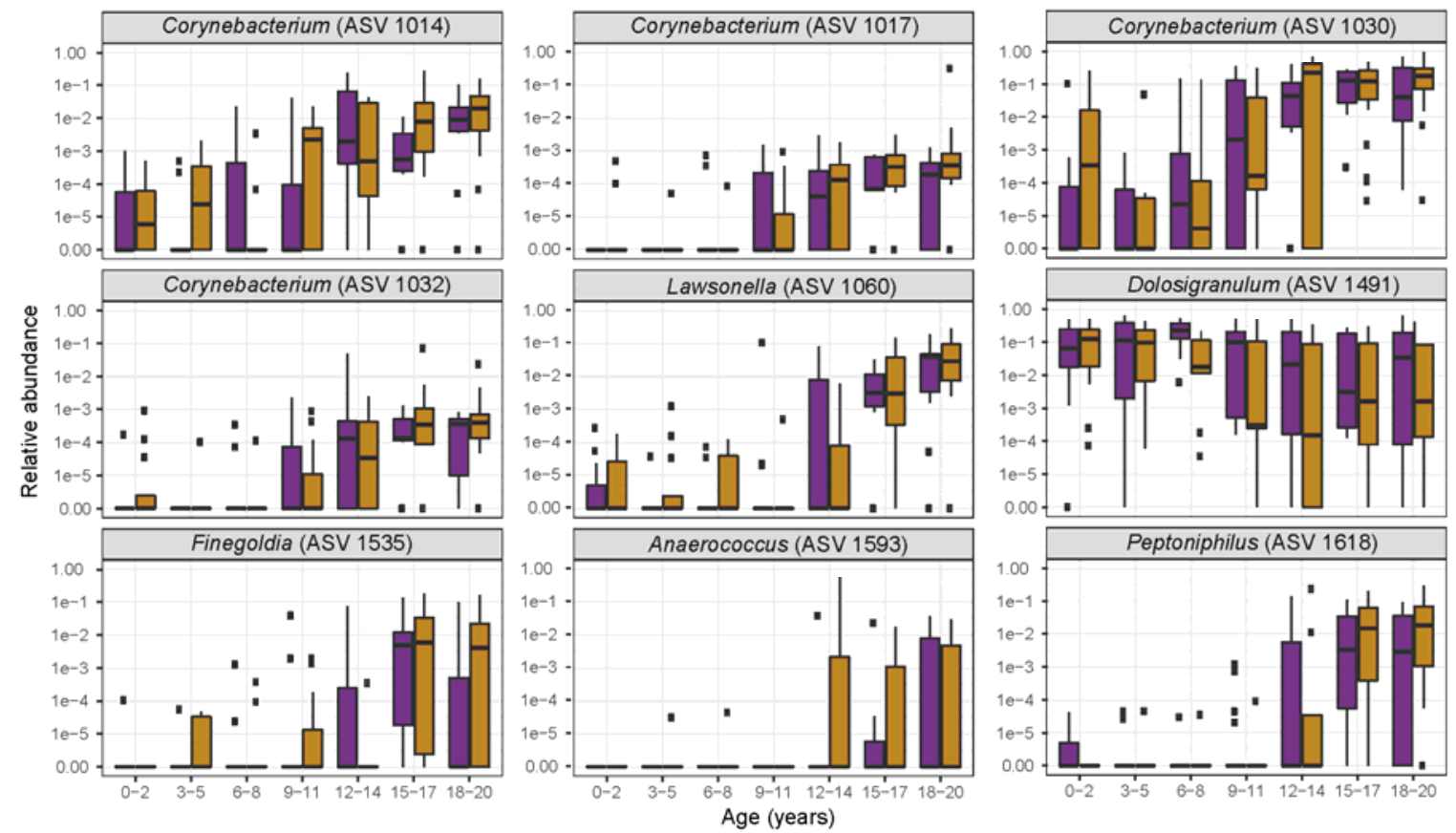

Respiratory symptoms 卢 No 官 Yes

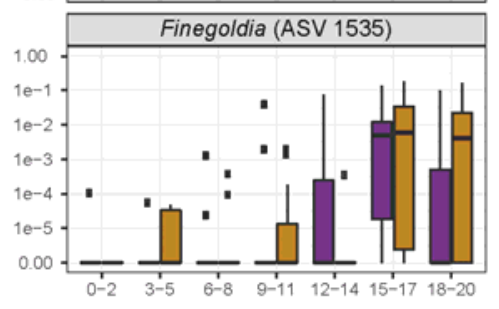

Figure 4. Relative abundances of ASVs that were differentially abundant by SARS-CoV-2-

associated respiratory symptoms. a) Boxplots of the relative abundances of ASVs that were differentially abundant by the presence of respiratory symptoms in SARS-CoV-2-infected individuals in age-adjusted analyses performed in ANCOM-II. b) Boxplots of the relative abundances by age group of ASVs that were differentially abundant by SARS-CoV-2 infection status in age-adjusted analyses 
1 conducted in ANCOM-II. Relative abundances are plotted on a log scale with 1E-6 added to all counts to

2 enable transformation of zero counts. Rectangles represent the lower quartile, median, and upper quartile

3 of the relative abundances of each ASV. Adjusting for age, SARS-CoV-2-associated respiratory

4 symptoms were associated with higher abundances of ASVs assigned to Corynebacterium spp. (ASV

5 1014, W=268; ASV 1017, W=233; ASV 1030, W=271; ASV 1032, W=229), Lawsonella clevelandensis

6 (ASV 1060, W=273), Finegoldia magna (ASV 1535, W=265), Anaerococcus spp. (ASV 1593, W=231),

7 and Peptoniphilus spp. (ASV 1618, $W=271$ ). The relative abundances of each of these ASVs additionally

8 increased with increasing age adjusting for SARS-CoV-2 infection status and the presence of SARS-CoV-

9 2-associated respiratory symptoms (ASV 1014, W=173; ASV 1017, W=170; ASV 1030, W=173; ASV

10 1032, $W=170 ;$ ASV 1060, $W=173$; ASV 1535, $W=172 ;$ ASV 1593, $W=169 ;$ ASV 1618, $W=173)$.

11 Adjusting for age, SARS-CoV-2-associated respiratory symptoms were associated with a lower

12 abundance of a single ASV assigned to Dolosigranulum pigrum (ASV 1491, W=260), and the relative

13 abundance of this ASV decreased with increasing age adjusting for SARS-CoV-2 infection status and the

14 presence of SARS-CoV-2-associated respiratory symptoms (ASV 1491, W=171). 
medRxiv preprint doi: https://doi.org/10.1101/2021.03.20.21252680; this version posted March 23, 2021. The copyright holder for this preprint (which was not certified by peer review) is the author/funder, who has granted medRxiv a license to display the preprint in perpetuity.

All rights reserved. No reuse allowed without permission.

\section{SUPPLEMENTAL MATERIALS}

3 Supplemental Table 1. Taxonomic classification and reference sequences for ASVs identified in 4 nasopharyngeal samples from the study population

5

6 Supplemental Table 2. Differentially abundant ASVs by age in ANCOM-II analyses adjusting for 7 SARS-CoV-2-infection status and SARS-CoV-2-associated respiratory symptoms

Supplemental Table 3. Prevalences and relative abundances of highly abundant bacterial genera by age

11 Supplemental Table 4. Differentially abundant ASVs by SARS-CoV-2 infection status in ANCOM-II 12 analyses adjusting for age

14 Supplemental Table 5. Differentially abundant ASVs among SARS-CoV-2-infected individuals by the presence of respiratory symptoms in ANCOM-II analyses adjusting for age

17 Supplemental Table 6. Differentially abundant ASVs in analyses comparing SARS-CoV-2-infected 18 individuals with respiratory symptoms to SARS-CoV-2-uninfected individuals in ANCOM-II analyses 
Table 1. Characteristics of the study population

\begin{tabular}{|c|c|c|c|c|c|c|c|}
\hline & \multicolumn{2}{|c|}{$\begin{array}{c}\text { SARS-CoV-2-Exposed, } \\
\text { Uninfected } \\
(\mathbf{n}=75)\end{array}$} & \multicolumn{2}{|c|}{$\begin{array}{c}\text { SARS-CoV-2-Infected } \\
\text { Without Respiratory } \\
\text { Symptoms } \\
(\mathrm{n}=88)\end{array}$} & \multicolumn{2}{|c|}{$\begin{array}{c}\text { SARS-CoV-2-Infected } \\
\text { With Respiratory Symptoms } \\
(\mathbf{n}=111)\end{array}$} & \multirow[t]{2}{*}{$\boldsymbol{P}$} \\
\hline & $\mathrm{N}$ (or median) & $\%$ (or IQR) & $\mathrm{N}$ (or median) & $\%$ (or IQR) & $\mathrm{N}$ (or median) & $\%$ (or IQR) & \\
\hline Age, years & 9.2 & $(5.0-16.7)$ & 9.1 & $(5.1-14.2)$ & 14.2 & $(6.5-17.5)$ & 0.006 \\
\hline Female sex & 38 & $51 \%$ & 49 & $56 \%$ & 57 & $49 \%$ & 0.77 \\
\hline Race & & & & & & & $<0.0001$ \\
\hline Black or African-American & 3 & $4 \%$ & 5 & $6 \%$ & 8 & $7 \%$ & \\
\hline Latino or Hispanic-American & 43 & $57 \%$ & 77 & $88 \%$ & 99 & $89 \%$ & \\
\hline Non-Hispanic white & 29 & $39 \%$ & 6 & $7 \%$ & 4 & $4 \%$ & \\
\hline \multicolumn{8}{|l|}{ Comorbidities } \\
\hline Provider-diagnosed asthma & 8 & $11 \%$ & 6 & $7 \%$ & 9 & $8 \%$ & 0.67 \\
\hline Obesity (BMI $\geq 95^{\text {th }}$ percentile for age) & 21 & $28 \%$ & 21 & $24 \%$ & 40 & $36 \%$ & 0.16 \\
\hline Receipt of antibiotic in prior 30 days & 1 & $1 \%$ & 2 & $2 \%$ & 3 & $3 \%$ & 0.88 \\
\hline Receipt of probiotic in prior 30 days & 2 & $3 \%$ & 0 & $0 \%$ & 1 & $1 \%$ & 0.37 \\
\hline
\end{tabular}

$\mathrm{IQR}$, interquartile range; BMI, body mass index 